\title{
EGY FELFEDEZÉS SIKEREI ÉS ÁRNYOLDALAI
}

\section{SUCCESSES AND DARK SIDES OF A DISCOVERY}

\author{
Furka Árpád \\ az MTA doktora, nyugdíjas egyetemi tanár, Eötvös Loránd Tudományegyetem \\ afurka2@yahoo.com
}

\begin{abstract}
ÖSSZEFOGLALÁS
A világ nagy gyógyszergyárai által használt kombinatorikus szintézis alkalmas akár több trillió új kémiai vegyület szintézisére, és léteznek olyan módszerek, amelyek lehetővé teszik, hogy ezek közül kiválaszthassák azokat, amelyekkel gyógyszerjelöltként tovább kísérletezhetnek. A kombinatorikus peptidtárak szintézisét és azok gyógyhatású komponenseinek meghatározási módszerét elsőként e cikk szerzője írta le egy közjegyző által 1982-ben hitelesített dokumentumban. Első publikálása 1988-ban történt két nemzetközi konferencián. A nyomtatott formában történő közzététel során az International Journal of Peptide and Protein Research főszerkesztője és a kézirat mindhárom feltételezett bírálója eltulajdonította a találmányt saját szabadalmi bejelentéseik és tudományos publikációik formájában. A szerző minden próbálkozása arra vonatkozóan, hogy a plágium nyilvánosságot kapjon, sikertelen volt. A negyedszázaddal későbbi próbálkozások többsége is kudarcba fulladt, és bebizonyosodott, hogy tudományos közlemények elbírálási módja kimondottan a plagizátoroknak kedvez. Ezért fontos a jövőben olyan változtatást bevezetni, amely a sértetteknek lehetőséget biztosít arra, hogy a plágiumot nyilvánosságra hozhassák abban a folyóiratban ahol azt elkövették.
\end{abstract}

\section{ABSTRACT}

The combinatorial synthesis applied by the big pharmaceutical companies makes it possible to synthesize even trillions of new compounds and identify new drug candidates by their screening. The synthesis of combinatorial peptide libraries and the potential identification of their biologically active components is first described by the Author in a document notarized in 1982. The first publication occurred in two international conferences in 1988. During the 1990-91 publication in the International Journal of Peptide and Protein Research the invention was expropriated by its editor-in-chief and all the three supposed reviewers and they utilized it in publications and patent applications. All attempts by the Author to get the plagiarism publicized had been unsuccessful. The same happened with the renewed attempts made a quarter of a century later. This proves that the present peer review system of scientific publishing definitely favours the plagiarists. It is important to provide for the victims possibility in the future to make the plagiarism public in the journal where it was committed.

Kulcsszavak: kombinatorikus kémia, kombinatorikus szintézis, DNS-sel kódolt kombinatorikus vegyülettárak, peptidek, plágium

Keywords: combinatorial chemistry, split-pool synthesis, DELs, peptides, plagiarism 


\section{BEVEZETÉS}

E cikk szerzője az 1964/65-ös tanévben ún. posztdoktori ösztöndíjjal a kanadai Alberta Egyetem Biokémiai Tanszékén végzett kutatásokat, amelyek révén sikerült meghatározni a kimotripszinogén-B nevü előenzim aminosavsorrendjét. Az enzimek fehérjék, amelyek aminosavakból épülnek fel, és az élő szervezetben lejátszódó kémiai folyamatokat képesek gyorsítani. A fehérjék szerkezetében a természetben található húszféle aminosav képviselői fordulnak elö, és láncszerüen kapcsolódnak össze. A fehérjék abban különböznek egymástól, hogy a láncban az egyes aminosavakból hány szerepel, és azok milyen sorrendben követik egymást. A kimotripszinogén-B-ben 245 aminosav fordul elö. Hazatérve, a szerző azon kezdett gondolkozni, hogy egy 245 aminosavból álló fehérjének hányféle egymástól különböző aminosavsorrendje lehet. Az eredmény egy elképesztően nagy szám volt: $20^{245}$, azaz 5,65 × $10^{318}$.

Ez a szám olyan nagy, hogy ha lenne egy olyan keverékünk, amelyben az említett lehetséges fehérjék csupán egyetlen molekulával lennének képviselve, annak együttes tömege több mint 200 nagyságrenddel nagyobb lenne, mint a világegyetem Albert Einstein által becsült tömege.

\section{A KOMBINATORIKUS KÉMIAI SZINTÉZIS}

A peptidek a fehérjékhez hasonló szerkezetủek, de bennük az aminosavak száma sokkal kisebb. A különböző számú aminosavat tartalmazó peptidek lehetséges száma is kiszámítható. A két, három, négy, öt és hat aminosavból álló peptidek száma például 400, 8000, 160 000, 3,2 millió és 64 millió. Mivel a peptidek között vannak olyanok is, amelyek hasznos biológiai hatást mutatnak, felmerült az a kérdés, hogy nem lehetne-e őket mind előállítani, és azután kiválasztani közülük a hasznosakat. Egy becslés azt mutatta, hogy az akkori legfejlettebb módszerrel a 3,2 millió ún. pentapeptid elóállítása egy vegyész folyamatos munkájával majdnem 44 ezer évig tartana. 1982-ben azonban sikerült egy olyan nagyon egyszerủ megoldást találni, amelynek segítségével ez a feladat egy vegyész számára a 44 ezer év helyett öt nap alatt megoldható volt.

A módszer az ún. szilárdfázisú szintézisen alapult, amelyért feltalálója, Bruce Merrifield professzor 1984-ben Nobel-díjat kapott. Ennek lényege, hogy az első aminosavat apró gyöngyökből álló polimerhez kapcsoljuk, majd folytatjuk a második, harmadik stb. aminosavval. Mivel a szintézis terméke a polimerhez van kapcsolva, a reagensek feleslegét és a melléktermékeket egyszerű szüréssel el lehet távolítani, és így a végén a terméket tiszta állapotban le lehet hasítani a polimerröl.

A mi módszerünk nagyon egyszerü, a következő müveletekből álló ciklus egymás utáni sorozatából áll: 
1. A polimert egyenlő adagokra osztjuk szét.

2. Mindegyik adaghoz más aminosavat kapcsolunk.

3. Az adagokat összekeverjük.

A ciklusokat addig folytatjuk, míg a peptidek elérik a tervezett aminosavszámot. A módszer alkalmas volt arra is, hogy peptideken kívül másfajta szerves vegyületeket is elő lehessen vele állítani. Ez az igen egyszerü módszer lehetővé tette, hogy egy vegyész egy hét alatt akár százmillió új vegyületet állíthasson elö, azaz többet, mint ahányat az összes vegyész elöállított a kémia teljes története alatt.

Ez az óriási teljesítmény azonban azzal a következménnyel járt, hogy a peptideket az előállítás folyamatának végén nem tiszta állapotban, hanem keverék formájában lehetett megkapni. Olyan megoldást is sikerült azonban találni, amelynek révén a keverékből ki lehetett választani a számunkra hasznos tulajdonsággal rendelkező peptideket.

A módszernek azonban volt egy olyan sajátsága is, hogy a szintézisnél használt polimergyöngyök mindegyikén csupán egyfajta peptid képződött. Ez azt jelentette, hogy az egy-egy gömböcskén képződő peptideket vagy más vegyületeket lehetett egyedileg is vizsgálni, és ha valamelyik gömböcskén levő vegyület hasznosnak bizonyult, akkor ezt követően annak szerkezetét külön kísérlettel kellett megállapítani.

Előre lehetett látni, hogy a módszernek igen nagy jelentősége lehet, különösen a gyógyszerkutatásban. Mivel a szabadalmaztatásra nem volt fedezet, a lehetőségekről konzultációt folytattunk a Chinoin gyógyszergyár szabadalmi ügyvivőjével (akivel a gyár részére végzett kutatásaink révén kapcsolatban álltunk), aki azt javasolta, hogy a találmány leírását hitelesíttessük közjegyzővel, hogy szükség esetén

\section{The first description of the principles of combinatorial chemistry}

Author: Professor Árpád Furka

Eötvös Loránd University Budapest Hungary English version

The original Hungarian document was notarized in June 15, 1982

......that is, when the compounds belonging to this type of compounds differ from each other only

in their building blocks or the sequences of these building blocks. Among them may occur natural compounds like oligosaccharides or oligonucleotides but synthetic products may be taken into account, too. Among these later ones one may think about sequential copolymers or sequential polycondensates.

dr. Arpad Furka university professor

File number 36237/1982

I certify this stitched document comprising 14, that is, fourteen pages was subscribed in my presence

by Dr. Arpad Furka, university professor, with his own hands.

Budapest, 1982. Nineteen hundred and eighty two, June 15, (fifteen).

Dr. Judit Bokai state notary public

1. ábra. A tanulmány leírását tartalmazó hitelesített dokumentum angol összefoglalójának részletei az első és utolsó oldalon

(A találmány leírását tartalmazó hitelesített dokumentum teljes szövege a cikk online változatának mellékleteként olvasható.) 
legyen bizonyítékunk a prioritásunkról és a publikációt is több lépésben végezzük. A 14 oldalas dokumentum hitelesítése 1982. június 15-én megtörtént.

Ebben a dokumentumban található a kombinatorikus kémia lényegének első megfogalmazása:

„A kutatási javaslat lényege az, hogy a peptideket nem egyenként szintetizáljuk, hanem olyan peptidkeverékeket állítunk elö, amelyek több száz vagy több ezer peptidet tartalmaznak, nagyjából azonos mol-arányban és ezeket a keverékeket vetjük alá hatásvizsgálatnak. Amint látni fogjuk ezen az úton a szintéziseknél és a hatásvizsgálatoknál egyaránt nagyon sok munkát lehet megtakarítani."

A módszer publikációja első ízben 1988-ban történt poszterek formájában egy prágai és egy budapesti nemzetközi kongresszuson. A hitelesített dokumentum publikációja később történt (Furka, 2002).

\section{SIKEREK}

A nyomtatásban történő közzététel évétől, 1991-től kezdve a módszer robbanásszerüen elterjedt különösen a gyógyszerkutatás világában, de átterjedt más tudományágak körére is, például az anyagtudományokra. Új tudományág alakult ki kombinatorikus kémia néven. A nagy gyógyszergyárak kombinatorikus csoportokat hoztak létre, de tucatjával alakultak új vállalkozások is erre a szintézismódra alapozva. Új kombinatorikus kémiai folyóiratokat alapítottak, és a tudományágnak nemzetközi szervezetei is kialakultak, amelyek konferenciák sorát rendezték. A Kombinatorikus Kémia Európai Szövetsége Budapesten rendezte első konferenciáját, amelyen a szerzőt a szövetség tiszteletbeli elnökévé választották. A sikerek olyan mértéket értek el, hogy az Amerikai Kémiai Társaság $C \& E N$ nevü hetilapja megkérdezte olvasóit arról, hogy vajon nincs-e már itt az ideje annak, hogy az új eredményeket Nobel-díjjal ismerjék el.

Ahogy azonban telt az idő, kiderült, hogy hiába állítottak elő a módszerrel sok új vegyületet, nem sikerült segítségével a remélt számban új gyógyszerjelölteket találni. Ezért a nagy gyógyszergyárak áttértek arra, hogy nagy (többmilliós) számban vásároltak kisebb cégektől egyedi vegyületeket, amelyek hatását aztán nagy teljesítményü (ún. HTS) módszerekkel vizsgálták. Ez azonban nagyon költséges volt.

\section{DNS-KÓDOLÁSÚ KOMBINATORIKUS VEGYÜLETTÁRAK}

1992-ben tehát nagyon korán, egy később nagyon fontos módosítás történt a módszerben. A Nobel-díjas Sydney Brenner és munkatársa, Richard A. Lerner azt javasolták, hogy a vegyületek szintézise közben a polimerszemcsékhez pár- 
huzamosan az aminosavval egy olyan DNS- (dezoxiribonukleinsav) szakaszt kell kapcsolni, amely nukleotidsorrendjében kódolja az éppen a szemcsékhez kapcsolt aminosavat (Brenner-Lerner, 1992). Ez azt jelentette, hogy ha egy szemcséről kiderült, hogy hasznos vegyületet hordoz, a peptid aminosavsorrendjét azonosítani lehetett az egymást követő kódoló DNS-szakaszok nukleotidsorrendjének meghatározása révén. Ennek a módosításnak több szempontból is jelentősége volt. Ha egy hasznosnak bizonyuló vegyület és annak DNS-szakasza csak nagyon parányi mennyiségben van is jelen, ezt a csekély mennyiséget az annak idején ugyancsak Nobel-díjjal jutalmazott ún. PCR-módszerrel szinte korlátlanul meg lehet növelni, és ezért nincs akadálya annak, hogy a nukleotidsorrendet a rendelkezésre álló módszerek valamelyikével meghatározhassák. A második szempontból azért nagyon jelentős ez a kódolási módszer, mert ma már a DNS-szakaszok nukleotidsorrendjét nagyon könnyủ és olcsó meghatározni.

Még egy jelentős módszerbeli módosítás történt. Ez akkor válik érthetővé, ha figyelembe vesszük a megosztásos-keveréses szintézismódszernek egy eddig nem említett sajátságát. Arról már volt szó, hogy a szintézis során minden szemcsén csak egyfajta peptid vagy más vegyület keletkezik, ami annak a következménye, hogy a folyamat során a keverékekhez mindig csak egyetlen újabb aminosavat (vagy más építőelemet) kapcsolunk. Ez egyébként, amint fentebb említettük, hasznos tulajdonsága a szintézismódszernek, van azonban egy hátrányos következménye is. Ez pedig az, hogy a polimerhordozón elöállítható vegyületek száma nem haladhatja meg a szemcseszámot. Ez a korlátozó hatás teljesen megszünik azáltal, hogy az említett második fontos módosítás teljesen kihagyja a polimerhordozó használatát. A szintézist oldatban hajtják végre, és maga a keletkező vegyületkeverék is oldható. Úgy a DNS-kódolásnak, mint a szilárd hordozó elhagyásának vannak hátrányos következményei is, amelyekkel azonban most nem foglalkozunk, de megjegyezzük, hogy az elönyei sokkal nagyobbak. A kombinatorikus éra kezdeti szakaszában elő́llított milliós tagszámú vegyülettárak után ma már milliárdos, sőt trilliós vegyülettárak is készülnek. Az egyik dán cég például 40 trilliós vegyülettárat készített, ami számokkal leírva 40000000000000 új vegyületet jelent. Mivel ezekben a vegyülettárakban a korábbiaknál sokkal több új vegyület van, bennük sokkal több hasznos vegyületet találtak.

A továbbiak megértéséhez tudnunk kell, hogy az élő sejtek működése a bennük levő vegyületek bonyolult kölcsönhatásán alapul. Ebben fontos szerepet játszanak a fehérjék, amelyek, mint említettük, aminosavakból felépülő óriásmolekulák. A gyógyszerek hatása azon alapul, hogy átmenetileg vagy végleg képesek hozzákapcsolódni egy fehérje felületének megfelelő részéhez, és ezáltal megakadályozhatják, hogy ahhoz egy másik fehérje vagy egyéb molekula hozzákapcsolódjon. Ezért a gyógyszerkutatók munkája azzal kezdődik, hogy először is azonosítanak 
egy úgynevezett célfehérjét, amelyről úgy vélik, hogy szerepe van valamelyik betegség kialakulásában. Ezután, azt vizsgálják meg, hogy lehet-e találni egy hozzákapcsolódó kismolekulát (vagy esetleg nagyot), amely meg tudja akadályozni a fehérjemolekulának egy másik molekulával történő kölcsönhatását, ami betegséghez vezethet. Erre akkor van remény, ha a kismolekula elég erősen tud hozzákötődni a célfehérjéhez. Ez képezi alapját a vegyülettárak szürésének annak érdekében, hogy a sok új vegyület között új gyógyszerjelölteket azonosíthassanak.

Ennek egyik módja az, hogy a célfehérjét egy szilárd hordozóhoz kapcsolják, majd összekeverik a vegyülettár oldatával. Egyes vegyületek hozzákapcsolódnak a fehérjéhez, a többit pedig szüréssel eltávolítják. Ezután a fehérjéről leoldják a hozzákapcsolódott vegyületeket, ezek DNS kódjának mennyiségét az említett PCR-módszerrel megnövelik, majd meghatározzák azok nukleotidsorrendjét. A nukleotidok sorrendjéből kiolvasható a kérdéses vegyületek szerkezete. Ezután következik a vegyületek egyenkénti kémiai szintézise és hatékonyságuk hosszadalmas vizsgálata.

A DNS-kódolású vegyülettárak szürésénél elegendő parányi mennyiségủ anyagot használni. Például Hofeng Deng és munkatársai négymilliárd komponenst tartalmazó vegyülettáruk szürésénél a célfehérjéből mindössze 0,000010 grammot használtak, a vegyülettár egy-egy komponense pedig mindössze 300000 molekulával volt képviselve, miközben egy mol vegyületben $6 \times 10^{23}$ molekula van (Deng et al., 2012). Ezért az elóállított vegyülettár rendszerint elegendő több ezer szürési kísérlet elvégzésére.

A DNS-kódolású vegyülettárak rendkívüli fontosságra tettek szert a gyógyszerkutatásban. Világszerte minden nagy gyógyszergyárban használják ezeket, sőt kihasználásuk érdekében konzorciumok is létrejöttek. Használatuk révén dollármilliárdokat takaríthatnak meg. Egyes gyógyszergyárak ingyen mintákat bocsátanak egyetemi kutatócsoportok rendelkezésére annak érdekében, hogy minél jobban kihasználhassák a bennük rejlő lehetőségeket.

\section{AZ ÁRNYOLDALAK}

A kombinatorikus szintézismódszer első publikációja 1988-ban történt poszter formájában egy prágai és egy budapesti nemzetközi kongresszuson, ahol semmiféle feltünést nem keltett. A nyomtatott formában történő közzététel érdekében a kéziratot 1990 februárjában küldtük el Victor Hruby professzornak (University of Arizona), az International Journal of Peptide and Protein Research címü folyóirat föszerkesztöjének. A cikket elöször visszautasították, de végül elfogadták, és 1991 júniusában jelent meg (Furka et al., 1991). A két időpont között azonban olyan dolgok történtek, amelyek súlyos árnyékot vetnek a tudományos publikálás ún. peer review (szakértői értékelés) rendszerére. 


\section{A FELFEDEZÉS ELTULAJDONÍTÁSA \\ AZ INTERNATIONAL JOURNAL OF PEPTIDE AND PROTEIN RESEARCH CÍMÜ FOLYÓIRATBAN TÖRTÉNŐ PUBLIKÁLÁS SORÁN}

Az ügy azzal kezdődött, hogy az Arizonai Egyetemen müködő Selectide Corporation (Tucson, Arizona, USA) alelnöke Budapestre jött, és meghívta a szerzőt, hogy tartson előadást az Arizonai Egyetemen, és folytasson tárgyalásokat a tudományos együttműködésről. Az előadás meg is történt 1991. április másodikán. Konzultánsi megbízást (évi 5000 dollárral) is felajánlottak, ami azonban elfogadhatatlan volt, mert a tudományos együttműködést olyan területre terelte volna, amely távol állt a később kombinatorikus kémiának nevezett szakterülettől.

A rossz hírek valamivel később jöttek. Egy régebbi munkatárs részt vett a 12. Amerikai Peptidszimpóziumon, ahol elmondása szerint dr. Kit S. Lam, az Arizonai Egyetem munkatársa és a szerző előadásának egyik hallgatója a kombinatorikus szintézist (a szerzők között Hruby professzorral) saját felfedezéseként adta elő. Az egyik kolléga Canterburyben vett részt az ún. Szilárdfázisú Szintézisek második nemzetközi szimpóziumán, ahol elmondása szerint dr. Richard A. Houghten (Torrey Pines Institute for Molecular Studies, San Diego, USA) előadásában szintén a sajátjaként beszélt a kombinatorikus szintézisről. Ugyanebben az évben mindkét említett előadó és munkatársaik cikket jelentettek meg a Nature címü folyóiratban, amelyben az említett találmány a sajátjukként van leírva (Lam et al., 1991; Houghten et al., 1991). A Lam-féle cikkben szerzőként szerepel a már említett fószerkesztő, Hruby profeszor is. A Nature olvasottsága sokkal nagyobb, mint az International Journal of Peptide and Protein Research című folyóiraté. Kezdetben főleg csak Lam és Houghten cikkeit idézték, saját cikkünk idézése sokkal később kezdődött el, és az ő idézetségük máig is nagyobb.

Később kiderült, hogy a fentebb említett időszakban négy szabadalom iránti kérelmet is benyújtottak, amelyek tárgya a kombinatorikus szintézis volt, és később a szabadalmakat el is fogadták.

A négyes szám nem véletlen, ugyanis megegyezik azok számával, akik elolvashatták a szerző kéziratát: a folyóirat főszerkesztője és a három bíráló. Megjegyzendő, hogy Lam is és Houghten is a szabadalmában hivatkozik az egyik 1988-as poszterre, azonban a hónapokkal később a Nature-höz benyújtott kéziratban már nem. Ez világosan bizonyítja a plágiumot, és rámutat arra a felháborító eseményre, hogy egy tudományos folyóirathoz benyújtott kézirat igen jelentős felfedezést leíró tartalmát eltulajdoníthatta a folyóirat főszerkesztője és a cikk mindhárom feltételezett bírálója. Egy ilyen rendkívül súlyos plágium bekövetkezése után az ember azt gondolhatná, hogy a tudományos publikációs rendszer korrigálni igyekszik, és netán súlyosan büntet is, hogy elvegye mások 
kedvét attól, hogy hasonlóan járjanak el. Ez azonban tévedés. Az eset óta eltelt évtizedek azt mutatják, hogy a kiadók és folyóirataik védeni igyekeznek magukat a botránytól, és inkább elkenik az eseteket ahelyett, hogy a hibákat kijavítanák. Ez az eljárás kiváló lehetőségeket teremt a plagizátoroknak, és súlyos veszteségeket a kárvallottaknak.

\section{SIKERTELEN PRÓBÁLKOZÁSOK A KORREKCIÓRA}

A fentebb leírt események után az első teendő a Nature-nek küldött korrigáló levél volt. A folyóirat akkori föszerkesztöje, Dr. John Maddox azonban annak publikálását minden különösebb indokolás nélkül elutasította.

A Hruby-csoport a kombinatorikus szintézissel kapcsolatos kutatásokra több mint hárommillió dolláros támogatást kapott. Az adott időszakban a szerző az amerikai AdvanceChem Tech cégnél volt tudományos tanácsadó, és kikérhette a pályázat szövegét. Ebből kiderült, hogy a pályázatban is sajátjukként tüntették fel a kombinatorikus szintézist, anélkül, hogy a szerző publikációira, amelyeket nyilvánvalóan ismertek, bármiféle utalást tettek volna. Emiatt indult hosszas levelezés Dr. Alan Price-szal, annak az intézménynek a képviselőjével (Office of Research Integrity of the Department of Health \& Human Services of the U.S.), amelytől a Hruby-csoport a kutatási támogatást kapta, aki azonban nem látott okot arra, hogy bármit is lépjen.

Végül levél ment az eset ismertetésével az International Journal of Peptide and Protein Research című folyóirat kiadójához (Munksgaard International Publishers, Copenhagen), de intézkedés ekkor sem történt.

A plagizátorok befolyásos személyek voltak. Hruby professzor a történtek idején az Amerikai Peptidtársaság elnöke volt, dr. Houghten pedig 2007 és 2008 között volt elnöke ugyanezen társaságnak. Ennek következtében akadályozhatták a szerző publikációinak elfogadását és a kongresszusokon tartandó előadásokat. Erre a legjobb példa, ami a kanadai Edmontonban tartott amerikai peptidszimpóziumon történt, ahol dr. Lam is és dr. Houghten is elöadást tarthatott, a szerző viszont csak poszterekkel szerepelhetett. A szekció elnöke később elmondta, hogy a szervezők arra utasították, hogy ha Furka szót kérne, azt ne adja meg.

A Nobel-díj Bizottság tagjai feltehetően tudhattak a plágiumról, mert az egyik tag 2004-ben felkereste a szerzőt, megnézte az 1982-es dokumentumot, és azt kérte, hogy gyorsan publikáljon egy cikket, amelyben leírja a plágium történéseit. Ilyen cikket azonban nem lehetett volna nemzetközi folyóiratban publikálni, ezért a Hargittai István professzorral közösen készített cikk a Budapesti Müegyetem folyóiratában jelent meg (Furka-Hargittai, 2004). 


\section{ÚJABB SIKERTELEN PRÓBÁLKOZÁSOK A KORREKCIÓRA EGY NEGYEDSZÁZADDAL KÉSŐBB}

A két fő plagizátor, Lam és Houghten az elkövetkező évek során cikkeikben szilárdan ragaszkodtak korábban megszerzett státuszukhoz, és a kombinatorikus kémiával foglalkozó cikkeikben főleg csak egymást idézték. Lam egyik 2017-ben közölt cikkében odáig ment el, hogy a szerzőt kihagyta a kombinatorikus kémia megalapítói közül, és helyébe saját magát helyezte. Ezen tény és annak reménye hatására, hogy az évtizedek során talán változott a plágiumok megítélése, a szerző helyesbítő leveleket küldött azon folyóiratokhoz, ahol a két említett szerző félrevezető adatokat publikált. Összesen tíz ilyen levél került elküldésre. Ezek közül csak három jelent meg, a többit elutasították.

Az elutasítások miatt panaszos levelek mentek több helyre. Az egyiknek a címzettje az Amerikai Kémiai Társaság Etikai Bizottsága volt, hiszen az elutasítók között e társaság folyóiratai is szerepeltek. A válasz ez esetben is elutasító volt. A bizottság elnöke azt válaszolta, hogy nem avatkozhat bele a társaság folyóiratainak ügyeibe. Az eset keserü fintora az, hogy a fő plagizátor, Victor Hruby, a volt föszerkesztő, jelenleg tagja az etikai bizottságnak!

A tudományos folyóiratok kiadóinak van egy közös szervezetük, amelynek neve COPE (Committee on Publication Ethics), és feladata a plágium elleni fellépés. Ennek azonban még azt sem sikerült elérnie, hogy a korrigáló levelek megjelenhessenek a kérdéses folyóiratokban.

A University of California Park Davishez (Kaliforniai Egyetem Park Davisi részlegéhez) is panaszos levél ment amiatt, hogy Lam professzor az egyetem honlapjain is sajátjaként tüntette fel a kombinatorikus szintézist. Még választ sem küldtek.

\section{KÖVETKEZTETÉSEK}

A fentebb leírt tények azt mutatják, hogy a folyóiratok többsége még a fentihez hasonló kirívóan durva plágium esetén is elutasítja a sértett próbálkozásait arra vonatkozólag, hogy a plágium ténye és elkövetőinek neve nyilvánosságra kerüljön, pedig ennek lenne visszatartó ereje. A fö felelősség a folyóiratok kiadóit terheli, hiszen ők választják ki a főszerkesztőket, akik elutasítják a panaszokat. Annak, hogy újabban a szerzőknek a kéziratuk benyújtásakor nyilatkozniuk kell arról, hogy nem plagizáltak, nincs visszatartó ereje. Olyan szabályokat kellene bevezetni, amely kimondja, hogy a plágium sértettjének nyilvánosságot kell biztosítani abban a folyóiratban, amelyben a plágiumot elkövették.

Az köztudott, hogy a plágiumot elkövetők ellen létezik a bírósági út lehetősége is. Ez az út azonban rendkívül költséges. Egy kutató vagy egyetemi alkalmazott fizetéséből erre nem futja, különösen akkor, ha az illető az egykori vasfüggöny 
mögötti országban él. A szerző erről beszélgetéseket folytatott kollégákkal és tudományos folyóiratok újságíróival. Ezeknek a beszélgetéseknek az volt a végkövetkeztetésük, hogy azoknak a szervezeteknek, amelyek a kutatásokat finanszírozzák, azokra az esetekre is forrásokat kellene tartalékolniuk, amelyek az esetleges plágiumperek költségeit fedeznék, hiszen a plagizátorok őket is megkárosítják akkor, amikor az általuk finanszírozott kutatások eredményeit eltulajdonítják.

\section{IRODALOM}

Brenner, S. - Lerner, R. A. (1992): Encoded Combinatorial Chemistry. Proceedings of the National Academy of Sciences of the USA. 89, 5381-5383. DOI: 10.1073/pnas.89.12.5381, https:// www.pnas.org/content/pnas/89/12/5381.full.pdf

Deng, H. et al. (2012): Discovery of Highly Potent and Selective Small Molecule ADAMTS-5 Inhibitors That Inhibit Human Cartilage Degradation via Encoded Library Technology (ELT). Journal of Medicinal Chemistry, 55, 7061-7079. DOI: 10.1021/jm300449x

Furka Á. et al. (1991): General Method for Rapid Synthesis of Multicomponent Peptide Mixtures. International Journal of Peptide and Protein Research, 37, 487-493. DOI: 10.1111/j.13993011.1991.tb00765.x, https://www.researchgate.net/publication/21239295_General_Method_ for_Rapid_Synthesis_of_Multicomponent_Peptide_Mixtures

Furka Á. (2002): Combinatorial Chemistry 20 years on... Drug Discovery Today, 7, 1-4. DOI: 10.1016/s1359-6446(02)00001-6

Furka Á. - Hargittai I. (2004): The Concealed Side of the History of Combinatorial Chemistry. Periodica Polytechnica Chemical Engineering, 48, 1, 13-19. https://pp.bme.hu/ch/article/ download/247/141/

Houghten, R. A. et al. (1991): Generation and Use of Synthetic Peptide Combinatorial Libraries for Basic Research and Drug Discovery. Nature, 354, 84-86. DOI: 10.1038/354084a0, https:// www.researchgate.net/publication/232779311_Generation_and_Use_of_Synthetic_Peptide_ Combinatorial_Libraries_for_Basic_Research_and_Drug_Discovery

Lam, K. S. et al. (1991): A New Type of Synthetic Peptide Library for Identifying Ligand-binding Activity. Nature, 354, 82-94. DOI: 10.1038/354082a0, https:/www.researchgate.net/publication/21210570_A_new_type_of_synthetic_peptide_library_for_identifying_ligand-binding activity 